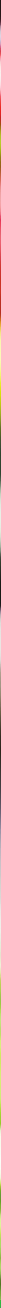

\title{
Food Economic Report 2016 of the Netherlands
}

Summary

P. Berkhout

WAGEN INGEN
UNIVERSITY \& RESEARCH 



\section{Food Economic Report 2016 of the Netherlands}

\section{Summary}

P. Berkhout

This project was financed by the Dutch Ministry of Economic Affairs from the public-private partnership 'Koepel Economische Informatievoorziening'.

Wageningen Economic Research

Wageningen, January 2017

BOOKLET

ISSN 0924-0764 
Berkhout, P., 2017. Food Economic Report 2016 of the Netherlands;

Summary. Wageningen, Wageningen Economic Research, Booklet. 16 pp.; 0 fig.; 5 tab.; 0 ref.

This booklet offers an English summary of the Voedsel-Economisch Bericht 2016 and Duurzaamheid en inkomens in de land- en tuinbouw (www.agrofoodportal.com). It presents a survey of the economic state of Dutch agribusiness. Attention is paid to the development of the agricultural complex, the food industry, the retail chain and the consumption of food. The booklet then proceeds to describe the production structure in the primary agricultural sector, profitability and income formation as well as the environmental performance of the agricultural sector.

This publication can be downloaded at http://dx.doi.org/10.18174/402121 or at www.wur.eu/economic-research (under Wageningen Economic Research publications).

(C) 2017 Wageningen Economic Research

P.O. Box 29703, 2502 LS The Hague, The Netherlands, $\mathrm{T}+31$ (0)70 33583 30, E communications.ssg@wur.nl, http://www.wur.eu/economic-research. Wageningen Economic Research is part of Wageningen University \& Research.

\section{(cc) BY-NC}

For its reports, Wageningen Economic Research utilises a Creative Commons Attributions 3.0 Netherlands license.

(C) Wageningen Economic Research, part of Stichting Wageningen Research, 2017

The user may reproduce, distribute and share this work and make derivative works from it. Material by third parties which is used in the work and which are subject to intellectual property rights may not be used without prior permission from the relevant third party. The user must attribute the work by stating the name indicated by the author or licensor but may not do this in such a way as to create the impression that the author/licensor endorses the use of the work or the work of the user. The user may not use the work for commercial purposes.

Wageningen Economic Research accepts no liability for any damage resulting from the use of the results of this study or the application of the advice contained in it.

Wageningen Economic Research is ISO 9001:2008 certified.

Wageningen Economic Research Booklet | Project code 2282300169

Cover photo: Shutterstock 


\section{Contents}

$\begin{array}{ll}\text { Preface } & 4\end{array}$

1 The Dutch agricultural sector 5

1.1 The agricultural complex 5

$\begin{array}{lll}1.2 & \text { Food and beverages industry } & 7\end{array}$

1.3 Retail chain and food consumption 7

$\begin{array}{lll}1.4 & \text { Trade in agricultural products } & 10\end{array}$

2 The agricultural and horticultural sector 12

2.1 Number of holdings and animals 12

2.2 Labour, land, and capital 13

2.3 The sector's income 14

$\begin{array}{ll}2.4 & \text { Environmental performance }\end{array}$ 


\section{Preface}

This booklet provides a summary of two publications, the Food Monitor 2016 (Voedsel-Economisch Bericht) and Sustainability and income development of the primary agricultural sector 2016 (Duurzaamheid en inkomens in de land-en tuinbouw). Both publications have been commissioned by the Ministry of Economic Affairs.

The Food Monitor is the successor to the Annual Agricultural Report and offers a global survey of the Dutch food economy. Attention is paid to the development of the agricultural complex, the food industry, the retail chain and the consumption of food. Based on the Sustainability and income development of the primary agricultural sector report, this booklet then proceeds to describe the production structure in the primary agricultural sector, profitability and income formation as well as the environmental performance of the agricultural sector.

The full versions of both publications (in Dutch) are available online via www.agrofoodportal.com. Part of the information on this website is also available in English.

The Hague, January 2017

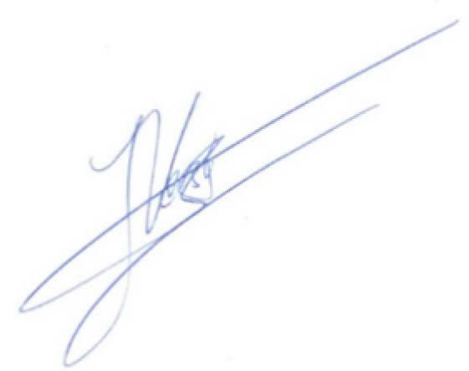

Prof.dr.ir. Jack (J.G.A.J.) van der Vorst

General Director Social Sciences Group

Wageningen University \& Research 


\section{The Dutch agricultural sector}

\subsection{The agricultural complex}

The agricultural sector - comprising agriculture, horticulture and fisheries is linked closely to other parts of the economy. For example, agricultural production is virtually impossible without provision of goods and services such as animal feed, fertiliser, energy, machinery, sheds, greenhouses, and veterinary and business services, whilst raw agricultural products require processing in the food industry, trade and distribution before they reach the consumers table. One can view the entire set of direct and indirect activities surrounding the agricultural sector as one inter-related chain, which we often refer to as the agro (or agricultural) complex.

The agro complex produces $8 \%$ of the national gross value added (GVA) The GVA from the entire Dutch agro complex was worth a good 48 million euro in 2014 (Table 1), which represented a little over $8 \%$ of the national gross value added. The share of the national total has increased slightly since 2010, which suggests that the agricultural complex has suffered relatively less from the financial and economic crisis since 2008 than other economic sectors.

Some of the activities involved in the agricultural complex relate to processing imported raw materials, such as cocoa, cereals and tobacco. The increase in the agricultural complex's contribution to national GVA results mainly from processing and distributing foreign raw materials. In the sector of the agricultural complex based on domestic raw materials, supply and primary production generate by far the largest contribution to GVA.

The agricultural complex provides a good $8 \%$ of national employment Employment in the entire agricultural complex has grown during recent years, reaching about 600,000 employment years in 2014 (Table 1), which represents $8.5 \%$ of the national total. This growth comes mainly 
from processing imported raw materials and the supply industry, while employment in the primary sector and distribution businesses declined.

Arable farming by far the most important sub-sector

The arable farming complex is the most important within the overall agricultural complex with a share of $47 \%$ in value and $39 \%$ in employment in 2014. That is partly due to the fact that importation and processing raw materials for livestock feed is allocated entirely to the arable farming complex. The land-based, livestock farming complex comes in second place (with a $19 \%$ and $26 \%$ share respectively). The greenhouse horticulture, intensive livestock, open-field horticulture and fisheries complexes each have a $15 \%$ share, or less, of the total agricultural complex GVA, and they account each for $13 \%$ or less of employment.

Table 1 Gross value added and employment in the Dutch agricultural complex, 2010, and 2014

\begin{tabular}{|c|c|c|c|c|}
\hline & $\begin{array}{l}\text { Added } \\
\text { value } \\
\text { ( } x \text { billion } \\
\text { euros) }\end{array}$ & $\begin{array}{l}\text { Added } \\
\text { value } \\
\text { (x billion } \\
\text { euros) }\end{array}$ & $\begin{array}{l}x 1,000 \\
\text { annual } \\
\text { labour } \\
\text { units }\end{array}$ & $\begin{array}{l}\text { x } 1,000 \\
\text { annual } \\
\text { labour } \\
\text { units }\end{array}$ \\
\hline & $<2010$ & $<2014$ & $<2010$ & $<2014$ \\
\hline $\begin{array}{l}\text { Total - domestic, and imported } \\
\text { agricultural raw materials complex }\end{array}$ & 44 & 48 & 579 & 599 \\
\hline Share in national total & $7.6 \%$ & $8.1 \%$ & $8.1 \%$ & $8.5 \%$ \\
\hline $\begin{array}{l}\text { Totals - imported agricultural raw } \\
\text { materials complex }\end{array}$ & 15 & 18 & 172 & 185 \\
\hline Share in national total & $2.6 \%$ & $3.0 \%$ & $2.4 \%$ & $2.6 \%$ \\
\hline $\begin{array}{l}\text { Total - domestic agricultural raw } \\
\text { materials complex }\end{array}$ & 29 & 30 & 407 & 414 \\
\hline Share in national total & $5.0 \%$ & $5.1 \%$ & $5.7 \%$ & $5.9 \%$ \\
\hline Primary production & 10 & 10 & 165 & 160 \\
\hline Processing & 4 & 5 & 56 & 61 \\
\hline Supply & 12 & 12 & 150 & 158 \\
\hline Distribution & 3 & 3 & 37 & 34 \\
\hline
\end{tabular}

Source: CBS (Statistics Netherlands) - processed by Wageningen Economic Research. 


\subsection{Food and beverages industry}

Measured by sales and employment, the food industry is the largest branch of industry. There are over 5,210 food companies, and they employ about 152,600 people. Several industrial sectors are included in these figures, from fruit and vegetable processing to abattoirs, meat products industry, bakeries and baked goods. The alcohol and tobacco industries are not included.

Almost one in six industrial employees works in the food industry. The largest group (76\%) comprises micro-businesses with fewer than ten employees, $17 \%$ are small businesses (with 10 to 50 persons), $6 \%$ are medium-sized (with a workforce of 50 to 250 ) and a good $1 \%$ consists of large companies (with more than 250 people employed).

The food industry represents an important part of the economy, turning over sixty-four billion euros, which represents a good $19 \%$ of total industrial turnover. When measured in number of jobs, the food industry's share is growing as well; the net revenue per job is higher than the national industrial average. Abattoirs and the meat processing industry, and the dairy industry, with sales shares at $16 \%$ and $19 \%$ respectively, are the most important sectors within the food industry.

The Dutch food industry has a number of large to very large multinational companies. FrieslandCampina and Unilever are good examples. They are active in many countries and several continents, where they have established important positions.

\subsection{Retail chain and food consumption}

In 2015, the total foodstuff turnover through all sales channels in the Netherlands reached a good fifty seven billion euros (Table 2). That sum involves retail sales (supermarkets and other retail outlets, e.g. markets and specialised businesses), and the food service sector (hotels and restaurants, catering, leisure and sales points 'on the move'). Retail sales represent a good two thirds of food and drink turnover, with 
supermarkets being the most important outlets. The food service sector accounts for about a third of total food and drink turnover.

Table 2 Food and drink turnover in the Netherlands, 2015, in billions of euros

\begin{tabular}{|c|c|c|c|}
\hline & & Turnover & $\begin{array}{l}\text { Market share of } \\
\text { food turnover, \% }\end{array}$ \\
\hline \multirow[t]{3}{*}{ Retail } & & 39.4 & 69 \\
\hline & supermarkets & 29.7 & 52 \\
\hline & other & 9.7 & 17 \\
\hline \multirow[t]{5}{*}{ Foodservice } & & 17.7 & 31 \\
\hline & hotels/restaurants/catering & 10.9 & 19 \\
\hline & leisure ${ }^{1)}$ & 1.2 & 2 \\
\hline & catering & 3.2 & 6 \\
\hline & on the move & 2.4 & 4 \\
\hline Food total & & 57.1 & 100 \\
\hline
\end{tabular}

1) Expenditure in recreation and amusement parks, etc.

Source: Foodstep (a Dutch food market advisory service), CBS and our own data.

The large supermarket chains such as Ahold (Albert Heijn), Jumbo, Lidl, and Aldi buy independently, while the smaller chains are members of the wholesale purchasing cooperative Superunie. Ahold tops the league for turnover and market share in the Netherlands. In 2015, Ahold realised almost 13 billion euros of turnover, which represents a good $35 \%$ market share. Jumbo comes in a safe second, with a good $17 \%$ market share and turnover at a good six billion euros in 2015. Lidl and Aldi are in third and fourth position.

\section{Increased household expenditure on food}

In 2015, Dutch households spent more than 290 billion euros on food, semi-luxury foods and beverages, tobacco, consumer durables, energy, water, fuel, and services, including hotels, restaurants, and catering. The largest sum was expenditure on housing, at fifty eight billion euros. Almost forty four billion euros went on durable goods, e.g. clothing, shoes, interior fittings, devices and such like. Total expenditure on food and semi-luxury foods, was equal, at forty four billion euros (Table 3 ). From that sum, about two thirds of the expenditure was on foodstuffs, 
e.g. dairy products, meat, and fish, potatoes, vegetables and fruit, and bread. The remaining expenditure was on semi-luxury items such as ice creams, candies, beverages and tobacco. Expenditure on food, semiluxury foods, beverages and tobacco amounted to $14.8 \%$ of total consumer spending on goods and services in 2015 . This proportion has remained quite stable for a few years (Table 3 ).

Table 3 Household consumer expenditure (billions of euros) a) 2012-2015

\begin{tabular}{|c|c|c|c|c|}
\hline & 2012 & 2013 & 2014 & 2015 \\
\hline Foodstuffs & 26.2 & 26.8 & 27.0 & 27.8 \\
\hline $\begin{array}{l}\text { Semi-luxury foods, } \\
\text { beverages and tobacco b) }\end{array}$ & 15.5 & 15.5 & 15.7 & 15.9 \\
\hline $\begin{array}{l}\text { Total on food and semi- } \\
\text { luxury items c) }\end{array}$ & 41.7 & 42.2 & 42.7 & 43.7 \\
\hline $\begin{array}{l}\text { Total consumer expenditure } \\
\text { on goods and services }\end{array}$ & 282.7 & 284.4 & 287.5 & 294.1 \\
\hline $\begin{array}{l}\text { Share }(\%) \text { foodstuffs and } \\
\text { semi-luxury foods, drinks, } \\
\text { and tobacco }\end{array}$ & 14.8 & 14.9 & 14.9 & 14.8 \\
\hline \multicolumn{5}{|l|}{ a At current prices } \\
\hline \multicolumn{5}{|l|}{ b Including tobacco } \\
\hline \multicolumn{5}{|c|}{$\begin{array}{l}\text { Relates to consumer spending through trade or directly. Expenditure on the catering industry is not } \\
\text { included }\end{array}$} \\
\hline
\end{tabular}

One can attribute the five per cent increase in total consumer spending on foodstuffs during the period 2012-2015 partially to price inflation. Most products became more expensive between 2012 and 2015.

\section{Large fluctuations in farm-gate prices}

For most products, consumer prices follow price increases or reductions earlier in the chain. The larger price fluctuations of products at farmgate level are somewhat muted by the processing industry, because the output price from the industry includes other costs, e.g. packaging, labour and energy. The retail sector, in turn, creates a dampening effect on raw material price fluctuations, because longer-term contractual agreements with suppliers lay off fluctuations in the processing 
industry's price index during the contract's duration. The costs of shop employees, buildings, gas, water and energy all contribute to the cost price of a consumer product. In addition, the retailer often has its own consumer policy per product group, on which the purchase price has only limited influence. If price increases or reductions at retail level are developing differently than the input costs, we usually see the store's inhouse price policy prevailing.

Consumption of foodstuffs from sustainable and organic production has grown for five subsequent years

Consumption of foods certified as organic or originating from sustainable production has increased during recent years. Sustainable food comes from a production system that takes more account of the environment, animal welfare, and/or social aspects than is legally required. The market share of foodstuffs with one or more, independently inspected, sustainability quality mark(s) amounts to a total of 2.6 billion euros, and increased from $6 \%$ in 2013 to $7 \%$ in 2014. In 2014, consumers have for the fifth consecutive year bought more food from animal, human and environmentally friendly production .

\subsection{Trade in agricultural products}

Many one-man businesses in the wholesale sector

The agricultural product wholesale sector comprises trade in agricultural products and livestock, and wholesale trade in foodstuffs. With turnover at a good 118 billion euros in 2014, agricultural product wholesaling represents a substantial and growing part of the Dutch wholesale sector, which handled a volume of 414 billion euros in 2014 . The 14,600 companies involved in the wholesale trade of agricultural products provide employment to 144,000 people, which is $29 \%$ of total employment in the wholesale sector.

Agricultural product wholesaling is very fragmented. The sector comprises many small to very small businesses. The average number of employees is not even ten people. One-man businesses account for almost sixty per cent of the total number of companies involved in the sector. Only one hundred and twenty companies have 100 employees or more, and there 
are more large companies in the foodstuff wholesale sector than there are in agricultural product wholesaling. Agricultural product wholesaling is highly oriented towards foreign markets. In fact, two thirds of trade turnover in arable products, as well as flowers and plants, comes from abroad. Foodstuff wholesaling is much less oriented at foreign markets.

Slight increase in exports

In 2015, Dutch agricultural exports exceeded 81.6 billion euros (Comtrade, 2016), an increase of $0.5 \%$ compared to 2014 . After the United States, the Netherlands is the second biggest agricultural exporter in the world. The exports include a wide range of products, which go primarily to immediate neighbours. In 2015, Germany, Belgium, the United Kingdom and France accounted for $55 \%$ of the exports.

The most important export products are vegetables and fruit, live animals and meat, and flowers and plants.

Import value of agricultural products into the Netherlands increases again In 2015, the value of imported agricultural products was 55.2 billion euros, an increase of $4.3 \%$ compared to 2014. Imports from EU countries have remained fairly stable at around $60 \%$.

The most important source countries for imports from within the EU are Germany, Belgium, France, and the United Kingdom, with a combined share of $43 \%$ of the total import value. The share is stable to slightly decreasing. The important import source countries outside the EU are Brazil, the United States, and Indonesia. The share of imports coming from those countries is still limited to about $10 \%$. Just like exports, imports are multidimensional. Important examples of imported products include vegetables and fruit, meat, live animals, and cacao.

More than half of Dutch agricultural exports are foodstuffs Agricultural trade figures are the sum total of data gathered on more than 2,300 commercial codes, which cover different products, ranging from seeds to processed meat. More or less directly consumable food or beverages represented about $58 \%$ of Dutch agricultural exports in 2015, and amounted to 47 billion euros. 


\section{The agricultural and horticultural sector}

\subsection{Number of holdings and animals}

In 2015, the total number of agricultural and horticultural businesses declined by 1,600 to 63,900 (Table 4 ). This $2.4 \%$ decrease is equal to the average annual decrease over the last five years, and somewhat less than it was in $2000(-2.8 \%$ per annum).

Table 4 Developments in the numbers of holdings and employees, and total area of farmland from 2000 onwards

\begin{tabular}{lllll} 
& 2000 & 2005 & 2010 & 2015 \\
$\begin{array}{l}\text { Number of agricultural and } \\
\text { horticultural farms }(\times 1,000)\end{array}$ & 97,389 & 81.750 & 72.324 & 63.900 \\
\hline Number of workers (x 1,000) & 280.9 & 235.7 & 212.0 & 186.0 \\
\hline Area of farmland (x 1,000 ha) & $1,975.5$ & $1,937.7$ & $1,872.3$ & $1,846.0$ \\
\hline
\end{tabular}

Source: CBS (Statistics Netherlands) agricultural census, processed by Wageningen Economic Research.

Big and increasing differences in business size

The size of businesses in Dutch agriculture and horticulture varies hugely, from a large number of very small businesses ( $43 \%$ of all businesses in 2015) to a small number of very big ones (6\% in 2015). The first group only represents $3 \%$ of the total gross value added (based on standard earning capacity), while the second manages to produce $43 \%$ of it.

A lot more dairy cattle and less sheep

The cattle population in the Netherlands rose to 4.1 million in 2015. During the period from the introduction of milk quotas in 1984 and up to 2007, the number of dairy cows reduced from 2.5 to 1.4 million. But, expansion and the end of quotas (April 2015) led to an increase to 1.6 million animals by 1 April 2015, with a further increase to 1.7 million 
by 1 December 2015 . The dairy herd actually increased by $16 \%$ between early 2012 and late 2015 . The number of young livestock for milk production increased by a comparable amount.

The number of other types of grazing livestock increased by $1 \%$ in 2015 . In 2015 , there were about 900,000 sheep and around 470,000 goats.

Number of pigs very stable, but more chickens

At the end of 2015 , there were 12.5 million pigs, $2 \%$ more than at the beginning of 2014. From the turn of the century, pig numbers fell by $5 \%$. During recent years, the number of animals has remained quite stable, thanks to the limitation through 'pig rights' (an instrument to limit the manure production).

The number of chickens rose in 2015 by $3.6 \%$, reaching 107 million. The number of animals in this sector is also restricted through livestock rights (poultry rights).

\subsection{Labour, land, and capital}

The total number of people regularly employed in primary agriculture and horticulture fell by $2.3 \%$ in 2015 , to almost 186,000 (Table 4 ). This is less than the $2.7 \%$ average annual decrease since 2000. In 2015, $70 \%$ of the entire workforce were family members.

These figures exclude flexible labour (temporary workers from agencies and personnel with short-term contracts). The regular employees usually have full-time jobs all year round, while flexible employees, particularly in the open ground horticulture sector, only come in for peak periods. The total size of the flexible workforce is therefore difficult to determine.

Share of grassland still increasing

Registered Dutch agricultural and horticultural enterprises in 2015 had 1.85 million hectares of land in use (Table 4). This represents a small increase $(0.4 \%)$ compared to the previous year. Regulatory changes may underlie such short-term changes. Over the longer-term acreage has decreased, averaging $0.5 \%$ less per year since 2000 . 
Fifty-five per cent of the total area of cultivated land is now in use as grassland (permanent, temporary and natural), $13 \%$ for green fodder crops, $27 \%$ for other arable production, $5 \%$ for open-field horticulture and $0.5 \%$ for greenhouse horticulture. The share taken up by grassland and animal feed crops has increased from $63 \%$ to $67 \%$ since 2000 , while the arable area has decreased from $32 \%$ to $27 \%$.

Balance sheet value of agriculture and horticulture has stabilised since 2014

The average balance sheet value of Dutch agricultural and horticultural businesses was 2.7 million euros at the end of 2014, virtually the same as in 2013. Two thirds of that is financed with in-house capital.

Since the beginning of this century, the average book value of agricultural and horticultural holdings increased by around 1.1 million euros, mainly due to increased average farm size and higher farmland prices. By the end of 2014, the land represented more than half of the total balance-sheet value, compared to $36 \%$ in 2001 .

\subsection{The sector's income}

The estimated total amount of factor income (returns from the production factors land, capital and labour) from the entire agriculture and horticulture sector for 2016 is nearly 7.3 billion euros. In 2016, the income per annual labour unit (ALU) rose by $7.6 \%$ compared to the previous year. The increase was mainly due to a combination of virtually unchanged revenues and decreased costs. Prices fell on fertiliser and energy in particular. The total production value of the sector remained the same as for 2015 .

The estimated average income from activities in agricultural and horticultural businesses in 2016 is about 53,000 euros per unpaid ALU, representing an increase of 6,000 euros compared to 2015. Every year, there are large income disparities in the agriculture and horticulture sector, both between, and within the different business types. 


\subsection{Environmental performance}

The environmental impact of the primary agriculture and horticulture sector is visible and measurable through different environmental indicators. There is wide ranging variation between developments connected with each environmental issue. For example, net energy consumption has dropped significantly, but particle emissions increased by $2.5 \%$. Phosphate production from the Dutch livestock farming rose again in 2015, with the dairy sector in particular contributing to the increase.

Decreased pesticide use, and greenhouse gas emissions stable Pesticide sales have been fluctuating at around 10 million $\mathrm{kg}$ of active ingredient per year. A good $40 \%$ of the substances used are for combating fungal infections. Fungal infection pressure is higher in years with wet summers than it is when the weather is dry.

Around $98 \%$ of total sales were for use in agriculture and horticulture. Retail users or public park and garden managers used the remainder, often weed control substances.

Greenhouse gas emissions from agriculture and horticulture in 2015 were similar to those of 2005, reaching more than twenty-seven metric tons of $\mathrm{CO}_{2}$ equivalents. During the period 2010-2015, emissions reduced by $18 \%$ compared to almost $34 \mathrm{Mt}$ of $\mathrm{CO}_{2}$ equivalents during the nineteen-nineties. In the Netherlands, the share of total greenhouse gas emissions attributable to agriculture and horticulture has decreased slightly from $15 \%$ in the nineties to 13 to $14 \%$ in the last ten to fifteen years. Methane from cattle accounts for about half of those emissions.

Levels of nitrogen en phosphates in soil decline, ammonia emissions stabilise

In the dairy farming sector, the amount of excess nitrogen and phosphates per hectare in the soil is at the lowest level since 1991, with the manure disposal regulations being an influencing factor here. In 2014 , the main cause of decreased surpluses was mineral taken up from the soil through high grass and corn production levels per hectare. 
Phosphate excesses decreased in the arable sector as well, while nitrogen surpluses stabilised.

Ammonia emissions have stabilised since 2010 at around 115 million $\mathrm{kg}$ of $\mathrm{NH}_{3}$. Dairy farming accounts for the largest share at 54 million kilograms, followed by pig production with 21 million, and then poultry at 14 million. Between 1990 and 2000, ammonia emissions reduced by more than half, mainly due to the low-emission application of manure. One can attribute the post 2000 decline in ammonia emissions primarily to an increase in the number of low-emission housing units now operating in intensive livestock farming, and to growth in processing, and exporting manure.

Table 5 Development of the environmental impact of agriculture and horticulture, 2000-2015

\begin{tabular}{|c|c|c|c|c|c|c|}
\hline & 2000 & 2005 & 2010 & 2013 & 2014 & 2015 \\
\hline $\begin{array}{l}\text { Use of crop protection } \\
\text { agents (in million } \mathrm{kg} \text { of } \\
\text { active substance) }\end{array}$ & 11.38 & 10.71 & 9.6 & 9.94 & 9.61 & N/A \\
\hline $\begin{array}{l}\text { Greenhouse gas } \\
\text { emissions (in billion } \mathrm{CO}_{2} \\
\text { equivalents, IPPC2013) }\end{array}$ & 29.3 & 27 & 29.9 & 28.3 & 27.2 & 27.6 \\
\hline $\begin{array}{l}\text { Surplus of nitrogen }(\mathrm{N}, \mathrm{kg} \\
\text { per hectare), arable farms }\end{array}$ & $106^{1)}$ & 126 & 110 & 111 & 100 & $\mathrm{~N} / \mathrm{A}$ \\
\hline $\begin{array}{l}\text { Surplus of phosphates } \\
\left(\mathrm{P}_{2} \mathrm{O}_{5}, \mathrm{~kg} \text { per hectare }\right), \\
\text { arable farms }\end{array}$ & $34^{1)}$ & 45 & 23 & 19 & 14 & $\mathrm{~N} / \mathrm{A}$ \\
\hline $\begin{array}{l}\text { Surplus of nitrogen }(\mathrm{N}, \mathrm{kg} \\
\text { per hectare), dairy farms }\end{array}$ & $186^{1)}$ & 179 & 172 & 170 & 149 & $\mathrm{~N} / \mathrm{A}$ \\
\hline $\begin{array}{l}\text { Surplus of phosphates } \\
\left(\mathrm{P}_{2} \mathrm{O}_{5}, \mathrm{~kg} \text { per hectare }\right) \text {, } \\
\text { dairy farms }\end{array}$ & $33^{1)}$ & 35 & 14 & 11 & -6 & N/A \\
\hline $\begin{array}{l}\text { Ammonia emissions (in } \\
\text { million } \mathrm{kg} \text { ) }\end{array}$ & 161 & 137 & 120 & 111 & 115 & 117 \\
\hline
\end{tabular}

1) 2002

N/A: not available

Sources: Plant Protection Service - RIVM (Dutch National Institute for Public Health and the Environment)/CBS, Milieucompendium (Environment Compendium), various years. 

The mission of Wageningen University and Research is "To explore the potential of nature to improve the quality of life". Under the banner Wageningen University \& Research, Wageningen University and the specialised research institutes of the Wageningen Research Foundation have joined forces in contributing to finding solutions to important questions in the domain of healthy food and living environment. With its roughly 30 branches, 5,000 employees and 10,000 students, Wageningen University \& Research is one of the leading organisations in its domain. The unique Wageningen approach lies in its integrated approach to issues and the collaboration between different disciplines.

Wageningen Economic Research

P.O. Box 29703

2502 LS Den Haag

The Netherlands

E communications.ssg@wur.nl

www.wur.eu/economic-research

\section{BOOKLET}

ISSN 0924-0764 